\title{
Biometrological methods to evaluate in vivo the skin hydratation of different commercial moisturizers containing $10.0 \%$ urea as the main claim
}

\author{
Métodos biometrológicos para avaliação, in vivo, da hidratação de diferentes cremes \\ comerciais contendo $10 \%$ de ureia em seu claim principal
}

\author{
César Augusto cecílio Chaves ${ }^{1}$, Marcelle Chamie D'Agostino¹, André Rolim Baby², Vânia Rodrigues Leite- \\ Silva ${ }^{1}$ \\ ${ }^{1}$ Instituto de Ciências Ambientais Químicas e Farmacêuticas, Universidade Federal de São Paulo, Diadema SP, Brasil \\ ${ }^{2}$ Faculdade de Ciências Farmacêuticas, Universidade de São Paulo, São Paulo, SP, Brasil \\ E-mail: vania.leite@unifesp.br
}

\begin{abstract}
The biometrological measurements of skin hydration and transepidermal water loss are important parameters to evaluate the moisturizing ability of creams and lotions suitable for this purpose. This study analyzed, through biometrological tests, the performance of five different commercial moisturizing creams containing $10.0 \%$ urea. The amount of water in the stratum corneum was analyzed by Corneometer ${ }^{\circledR}$, equipment that measures the skin hydration by capacitance principle. The transepidermal water loss was analyzed by TEWLmeter ${ }^{\circledR}$, equipment that measures water evaporation through the skin. Student t-tests were applied to these measures, which demonstrated significant differences between the hydration performances of the moisturizing creams analyzed. The moisturizer identified as "D" showed a better moisturizing ability and better prevented transepidermal water loss. Overall, results showed the importance of testing equivalence for topical products, since, as demonstrated in this study, although certain products may contain the same active substance, differences in their vehicles' composition can alter the effectiveness.
\end{abstract}

Keywords: Moisturizers; Skin hydration; Urea; Transepidermical water loss.

\section{Resumo}

As medidas biometrológicas referentes à hidratação cutânea e à perda de água transepidérmica são parâmetros importantes para avaliação da capacidade hidratante de cremes e loções indicados para tal finalidade. Este trabalho teve como objetivo principal a análise, através de testes biometrológicos, da performance hidratante de cinco tradicionais cremes do mercado que possuem a concentração de $10 \%$ de ureia como seu claim principal. Analisou-se a quantidade de água no estrato córneo através do Corneometer $\Re$, equipamento que utiliza o princípio de capacitância para medir a hidratação cutânea; e a perda de água transepidérmica, através do TEWLmeter ${ }^{\circledR}$, equipamento que mede a taxa de evaporação da água pela pele. Às medidas biometrológicas obtidas, foram aplicados testes do tipo t-Student, a partir dos quais ficou demonstrada a existência de diferenças significativas entre as performances de hidratação dos cremes analisados. O creme identificado como " $D$ " demonstrou melhor capacidade hidratante e melhor prevenção da perda de água transepidérmica.

Os resultados mostraram a importância da realização testes de equivalência também para produtos de aplicação tópica, uma vez que, conforme demonstrado neste estudo, apesar de alguns produtos conterem a mesma substância ativa, diferenças na composição de seus veículos podem alterar sua efetividade.

Palavras-chave: Hidratantes; Hidratação cutânea; Ureia; Perda de água transepidérmica. 


\section{Introduction}

The Brazilian cosmetic market grew $18.9 \%$ in 2011, holding the $3^{\text {rd }}$ position in the world rankings, preceded only by Japan and the United States, which grew $8.9 \%$ and $3.8 \%$, respectively. In 2013, Brazil may occupy the $2^{\text {nd }}$ position, due to the high consumption of cosmetics, in contrast to a reduction in consumption by the Japanese as a result of economic crisis [1].

Among the various cosmetic products, those with hydration appeal deserve attention, since they directly contribute to market growth. The skin has many functions, such as homeostasis and protection from chemical and physical agents, but they are performed best when this tissue functions properly. To make the skin function appropriately, two processes act together: cleaning and moisturizing [2].

When the skin integrity is impaired, the transepidermal water loss (TEWL) increases, resulting in xerosis, with specific signs and symptoms $[2,3]$. Dry skin may be treated or prevented with the use of moisturizers, which act on different mechanisms. The oils, in general, act as occlusive agents, thus avoiding the transepidermal water loss. Moisturizing substances, such as urea, have the capacity to retain water of formulation and water of environment. The body itself has a group of moisturizing substances in the stratum corneum which are called Natural Moisturizing Factor (NMF). Among these substances: amino acids, urea and lactic acid, which can also be incorporated into the cosmetic moisturizers $[4,5,6]$.

Due to its hygroscopic capacity, urea is extensively used as moisturizing agent in cosmetics. It is also naturally present in the stratum corneum, composing about $7.0 \%$ of the NMF $[7,8]$. In addition, urea has the effect of restoring the skin barrier, thus preventing irritations, as shown in experimental studies in which sodium lauryl sulfate was applied to skin previously treated with urea moisturizer $[8,9,10]$.

To measure the amount of water in the stratum corneum and the amount of water which is lost through the skin, two instruments were used: a Corneometer ${ }^{\mathbb{R}}$ and a Tewameter ${ }^{\circledR}$.

The Corneometer ${ }^{\circledR}$ is based on the principle of capacitance, since the stratum corneum is a dielectric medium, and this property changes according to its amount of water. The measurement consists of comparing the dielectric constant of water to other substances. The capacitor formed between the base Corneometer ${ }^{\circledR}$ probe and the skin shows changes in the value of capacitance, according to the amount of water in the skin. The Tewameter ${ }^{\circledR}$ can measure the rate of water evaporation, in $\mathrm{mg} /\left(\mathrm{cm}^{2} \mathrm{~h}\right)$, from skin surfaces based on Adolf Fick's law of diffusion [11].

\section{Introdução}

O mercado cosmético brasileiro apresentou crescimento de $18,9 \%$, em 2011, mantendo a terceira colocação no ranking mundial, atrás somente do Japão e dos Estados Unidos, que cresceram 8,9 \% e 3,8\% respectivamente. Acredita-se que, em 2013, o Brasil ocupará a vice-liderança, devido ao alto consumo de cosméticos, em contraste com redução do consumo por parte dos japoneses em decorrência de crise econômica [1].

Dentre os diversos produtos cosméticos, os que apresentam apelo de hidratação merecem destaque já que, por serem largamente comercializados, contribuem diretamente com crescimento do mercado.

A pele possui diversas funções como a homeostase e proteção contra substâncias químicas e físicas; porém elas são desempenhadas com excelência quando o tecido tegumentar estiver em condições normais e plenas de funcionamento e cuidado. Para que a pele esteja em estado adequado de funcionamento, dois processos básicos agem em conjunto: a limpeza e a hidratação cutânea [2].

Com a perda de integridade da barreira cutânea e desequilíbrio na descamação corneocítica, há um aumento da perda de água transepidérmica (TEWL) resultando em xerose, com seus sinais e sintomas característicos $[2,3]$.

A desidratação cutânea pode ser tratada ou prevenida com o uso de cosméticos hidratantes, que agem sobre a pele por diferentes mecanismos de ação. Os óleos, em geral, atuam como agentes oclusivos, evitando a perda de água transepidérmica. Substâncias umectantes, como a ureia, possuem a capacidade de reter água da formulação e do ambiente. O próprio organismo possui, no estrato córneo, substâncias umectantes, que compõem o chamado Fator de Hidratação Natural (NMF). Dentre essas substâncias, estão presentes: aminoácidos, ureia e ácido lático, que também podem ser incorporadas aos produtos cosméticos hidratantes $[4,5,6]$. Devido a sua capacidade higroscópica, a ureia é um agente hidratante amplamente utilizado em cosméticos, além de estar naturalmente presente no estrato córneo, constituindo cerca de $7 \%$ do NMF $[7,8]$. Além disso, a ureia possui efeito de restauração da barreira cutânea, prevenindo irritações, conforme estudo experimental de aplicação de lauril sulfato de sódio em pele previamente tratada com cremes contendo ureia $[8,9,10]$. Para a análise da quantidade de água no estrato córneo e daquela que se perde, são utilizados dois equipamentos: Corneometer ${ }^{\circledR}$ e Tewameter ${ }^{\circledR}$.

O Corneometer ${ }^{\circledR}$ baseia-se no princípio da capacitância, já que o estrato córneo seco é um meio dielétrico, e esta propriedade é alterada conforme a quantidade de água presente. A medida consiste na comparação da constante dielétrica da água com a de outras substâncias. $\mathrm{O}$ capacitor, formado entre a base da sonda Corneometer ${ }^{\circledR}$ e a pele, apresenta alterações no valor da capacitância conforme o conteúdo de água. Já o Tewameter ${ }^{\circledR}$ mede a taxa de evaporação de água na superfície da pele, em $\mathrm{mg} /\left(\mathrm{cm}^{2} \mathrm{~h}\right)$, com base na lei de difusão de Adolf Fick [11]. 


\section{Material and Methods}

\section{Type of study}

This was a blind and randomized study, in which biometrological methods were used to measure skin hydration and transepidermal water loss.

The study was approved by the Ethics Committee of the Federal University of São Paulo - UNIFESP / São Paulo Hospital platform through Brazil.

\section{Volunteers}

Eleven adult women, aged between 18 and 23 years, were selected. They were required to be free of any type of skin lesion, and there were no reports of allergy to moisturizers.

\section{Study site}

This study was conducted at Federal University of São Paulo, Diadema campus - José de Alencar Unit / Research Building, St. Nicholas Street, 210, in the Cosmetology laboratory. The temperature was controlled at $(22.0 \pm 2.0){ }^{\circ} \mathrm{C}$, and humidity was maintained at (45.0 $\pm 5.0) \%$.

\section{Equipment}

To measure the amount of water in the stratum corneum, reflecting the condition of skin hydration, a Corneometer ${ }^{\circledR}$ CM 825 PC Courage-Khazaka (Colónia, Alemanha) was used.

For the measurement of transepidermal water loss (TEWL), expressed in $\mathrm{g} /\left(\mathrm{m}^{2} \mathrm{~h}\right)$, a Tewameter ${ }^{\circledR} 300 \mathrm{TM}$ Courage-Khazaka (Colónia, Alemanha) was used.

\section{Procedures}

Five different well-known moisturizers, all containing $10.0 \%$ urea, were selected. They were named " $A$ " through "E" and their compositions are shown in Table 1.

Volunteers were previously instructed to not use any cream 48 hours before the experiment. They arrived at the laboratory 30 minutes early for environmental equilibration.

Two $\mathrm{mg} / \mathrm{cm}^{2}$ of each cream were weighed and applied to different areas of the forearms of volunteers. The application areas were each $3.0 \mathrm{~cm}^{2}$ and they were numbered from 1 to 6, in random order, as shown in Figure 1. Square number 1 corresponded to the area of application of cream " $A$ ", square number 2 to the cream $B$, and so on. Square 6 was used as a control, without application of product.

\section{Materiais e Métodos}

\section{Tipo do estudo}

Trata-se de um estudo cego, randomizado, no qual foram utilizados métodos biometrológicos para medida da hidratação cutânea e da perda de água transepidérmica.

Estudo Aprovado pelo Comitê de Ética da Universidade Federal de São Paulo - UNIFESP/ Hospital São Paulo através da Plataforma Brasil.

\section{Voluntárias}

Foram selecionadas 11 mulheres adultas, com idade entre 18 e 23 anos, que não apresentassem nenhum tipo de lesão cutânea ou qualquer relato de alergia a hidratantes.

\section{Local do estudo}

Este estudo foi desenvolvido na Universidade Federal de São Paulo, campus Diadema - Unidade José de Alencar / Prédio de pesquisa, Rua São Nicolau, 210, no laboratório de cosmetologia.

No laboratório, foi realizado controle de temperatura, mantida em $\left(22^{\circ} \mathrm{C} \pm 2\right){ }^{\circ} \mathrm{C}$, e de umidade relativa, que se manteve em $(45 \% \pm 5) \%$.

\section{Equipamentos}

Para análise da quantidade de água no estrato córneo, refletindo a condição de hidratação da pele, foi utilizado o equipamento Corneometer ${ }^{\circledR}$ CM 825 PC da marca Courage - Khazaka ${ }^{\circledR}$ (Colónia, Alemanha). Já para a perda de água transepidérmica (TEWL), utilizou-se o equipamento Tewameter ${ }^{\circledR}$ TM 300 da marca Courage - Khazaka ${ }^{\circledR}$ (Colónia, Alemanha). $\mathrm{O}$ equipamento Tewameter fornece valores em $\mathrm{g} /\left(\mathrm{m}^{2} \mathrm{~h}\right)$.

\section{Metodologia}

Foram selecionados cinco diferentes hidratantes comerciais consagrados, todos contendo $10 \%$ de ureia. Eles foram nomeados de "A" a "E" e suas respectivas composições seguem na Tabela 1.

As voluntárias foram previamente orientadas a não utilizar nenhum tipo de creme 48 horas antes do experimento. Elas chegaram ao laboratório com meia hora de antecedência, para ambientação.

Foram pesados $2 \mathrm{mg} / \mathrm{cm}^{2}$ de cada creme, e aplicados em áreas distintas do antebraço das voluntárias. Estas áreas foram delimitadas em $3 \mathrm{~cm}^{2}$ e numeradas de 1 a 6 , em ordem aleatória, conforme exemplificado na Figura 1. $\mathrm{O}$ quadrado de número 1 correspondeu à área de aplicação do creme A; o quadrado 2 , do creme $\mathrm{B}$ e assim por diante. O quadrado 6 foi utilizado como controle; sem aplicação de produto. 
Table 1 / Tabela 1. Qualitative composition of analyzed moisturizers

Composição qualitativa dos hidratantes analisados

\begin{tabular}{|c|c|c|}
\hline $\begin{array}{l}\text { Cremes } \\
\text { Creams }\end{array}$ & $\begin{array}{l}\text { Composição } \\
\text { Composition }\end{array}$ & $\begin{array}{c}\text { Claim principal } \\
\text { Main Claim }\end{array}$ \\
\hline A & $\begin{array}{l}\text { Aqua, } \\
\text { hydroxyethylcellulose, } \begin{array}{c}\text { glycerin, } \\
\text { urea, }\end{array} \\
\text { dissodium EDTA, shea butter } \\
\text { oleyl esters, butyrospermum } \\
\text { parkii butter, ceteareth-6 olivate, } \\
\text { dimethicone PEG-7 isostearate, } \\
\text { pentaerythrityl tetra-di-t- } \\
\text { butilhydroxyhydrocinnamate, } \\
\text { acrylates/acrylamide copolymer } \\
\text { and paraffinum liquidum and } \\
\text { polysorbate } \\
\text { cyclopentasiloxane, 85, } \\
\text { phenoxyethanol, } \\
\text { methysothizolinone, parfum, } \\
\text { citric acid, propylene glycol. }\end{array}$ & $\begin{array}{l}10 \% \text { ureia } \\
10 \% \text { urea }\end{array}$ \\
\hline B & 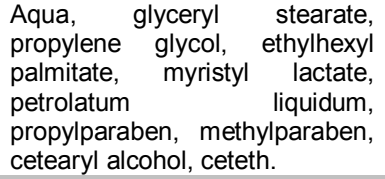 & $\begin{array}{l}10 \% \text { ureia } \\
10 \% \text { urea }\end{array}$ \\
\hline C & $\begin{array}{l}\text { Aqua, triethanolamine, PEG-8 } \\
\text { stearate, propylparaben, } \\
\text { dimethiconol and } \\
\text { cyclopentasiloxane, } \\
\text { methylparaben, cetyl alcohol, } \\
\text { urea, glyceryl stearate, } \\
\text { paraffinum liquidum, propylene } \\
\text { glycol, stearic acid. }\end{array}$ & $\begin{array}{l}10 \% \text { ureia } \\
10 \% \text { urea }\end{array}$ \\
\hline D & $\begin{array}{l}\text { Aqua, glycerin, urea, cetearyl } \\
\text { alcohol, caprylic/capric } \\
\text { triglyceride, ethylhexyl cocoate, } \\
\text { hydrogenated coco-glycerides, } \\
\text { octyldodecanol, paraffera } \\
\text { microcristallina, parafinum } \\
\text { liquidum, dmethicone, sorbitan } \\
\text { stearate, aluminum starch } \\
\text { octenylsuccinate, lactic acid, } \\
\text { phenoxyethanol, PEG-40 castor } \\
\text { oil, sodium cetearyl sulfate, } \\
\text { carbomer. }\end{array}$ & $\begin{array}{l}10 \% \text { ureia } \\
10 \% \text { urea }\end{array}$ \\
\hline$E$ & $\begin{array}{l}\text { Aqua, urea, isopropyl myristate, } \\
\text { paraffinum liquidum, glyceryl } \\
\text { stearate, PEG-40 stearate, } \\
\text { sorbitol, cetearyl } \\
\text { ethylhexanoate, dimethicone, } \\
\text { allantoin, carbomer, cetyl } \\
\text { alcohol, lactic acid, mannitol, } \\
\text { palmitic acid, persea gratissima } \\
\text { oil, sodium hydroxide, stearic } \\
\text { acid, parfum, benzyl salicylate, } \\
\text { 2-bromo-2-nitropropane-1,3- } \\
\text { diol, methylparaben, } \\
\text { propylparaben, alpha-isomethyl } \\
\text { ionone, citral, eugenol, hexyl } \\
\text { cinnamal, hydroxycitronellal, } \\
\text { limonene, linalool. }\end{array}$ & $\begin{array}{l}10 \% \text { ureia } \\
10 \% \text { urea }\end{array}$ \\
\hline
\end{tabular}

The measurements were performed before application, immediately after application and after $30 \mathrm{~min}, 60 \mathrm{~min}$, $120 \mathrm{~min}, 180 \mathrm{~min}, 240 \mathrm{~min}$ and $300 \mathrm{~min}$.

From the measurements performed in the intervals mentioned, the average value of hydration and the average value of transepidermal water loss of volunteers were calculated.
As medidas foram realizadas nos tempos: antes da aplicação; imediatamente após a aplicação; e após $30 \mathrm{~min}$, $60 \mathrm{~min}, 120 \mathrm{~min}, 180 \mathrm{~min}, 240 \mathrm{~min}$ e $300 \mathrm{~min}$ da aplicação.

A partir das medidas realizadas nos intervalos de tempo citados, calculou-se o valor médio de hidratação e o valor médio de perda de água transepidérmica dos voluntários. 


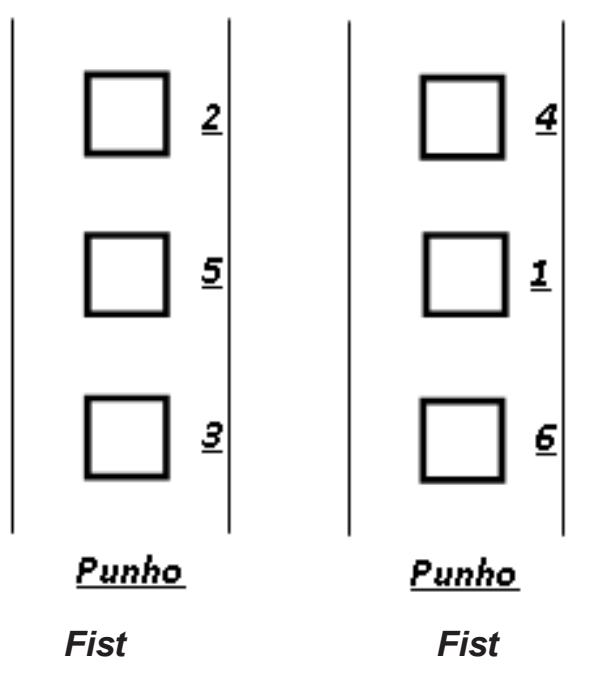

Figure 1 / Figura 1. Example of a random numerical order, chosen by one of the volunteers, for sample application

Exemplo da ordem numérica aleatória, escolhida por uma das voluntárias, para aplicação das amostras

\section{Results}

From data provided by Corneometer ${ }^{\circledR}$, the average skin hydration of each product was calculated, considering all the time intervals mentioned, as shown in Figure 2. Based on these values, Student t-tests were applied in order to compare product to product. These tests enabled the division of the products into groups according to the hydration capacity, as shown in Table 2. It was observed that the performance difference was significant between all moisturizing products, except between "A" and "E". It was also noted that, during the time interval studied, product D produced greater skin hydration, while "B" and "C" were not as effective.

\section{Resultados}

A partir dos dados fornecidos pelo Corneometer ${ }^{\circledR}$, calculouse a média da hidratação cutânea de cada produto, considerando todos os intervalos de tempo mencionados, conforme Figura 2.

Partindo-se desses valores, foram aplicados testes t-Student pareados, visando à comparação produto a produto. Esse tratamento de dados possibilitou a divisão dos produtos em grupos distintos quanto à capacidade de hidratação, conforme Tabela 2. Observou-se que a diferença de performance hidratante foi significativa entre todos os produtos, exceto entre "A" e "E". Também foi possível notar que, durante o intervalo de tempo analisado, o produto $\mathrm{D}$ foi o que conferiu maior hidratação cutânea às áreas em que foi aplicado, enquanto "B" e "C" não foram tão efetivos.

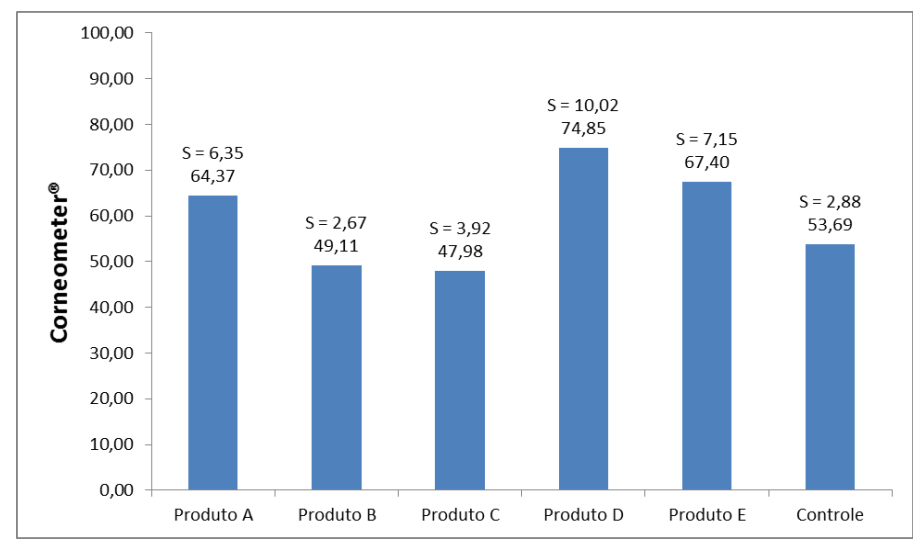

Figure 2 / Figura 2. Skin hydration averages of the areas where the products were applied and the control area over the total time of the study, displaying a $95 \%$ level of confidence

Hidratação cutânea média, ao longo de todo o estudo, nas áreas de aplicação dos produtos e na área controle, exibindo um nível de confiança de $95 \%$ 
Table 2 / Tabela 2. Products divided into groups, with significant differences in ability of skin hydration

Divisão dos produtos em grupos, com diferença significativa na capacidade de hidratação cutânea

\begin{tabular}{ccccccc}
\hline $\begin{array}{c}\text { Product/ } \\
\text { Produto }\end{array}$ & $\begin{array}{c}\text { Corneometer } \\
\text { Corneômetro }\end{array}$ & $\mathbf{1}$ & $\mathbf{2}$ & $\mathbf{3}$ & $\mathbf{4}$ & $\mathbf{5}$ \\
\hline $\begin{array}{c}\text { Product / Produto } \\
\text { C }\end{array}$ & 47,98 & $* * * *$ & & & \\
Product / Produto & & & & & & \\
B & 49,11 & & $* * * *$ & & \\
Control / Controle & 53,69 & & $* * * *$ & & \\
Product / Produto & & & & & \\
A & 64,37 & & & & & \\
Product / Produto & & & & & & \\
E & 67,4 & & & & \\
Product / Produto & & & & & \\
D & 74,85 & & & & &
\end{tabular}

The hydration capacity of each product, according to the time intervals analyzed, can be seen in Figure 3. As expected for moisturizing creams, products "A", "D" and "E" significantly increased skin hydration for up to five hours, relative to the control area, but products "B" and "C" were not shown to improve skin hydration compared to the control area.

Transepidermal water loss was measured in unit of $\mathrm{g} /$ $\left(\mathrm{m}^{2} \mathrm{~h}\right)$ by Tewameter ${ }^{\circledR}$ in the same time intervals. The average value was calculated for the fields of application of each product, as shown in Figure 4.

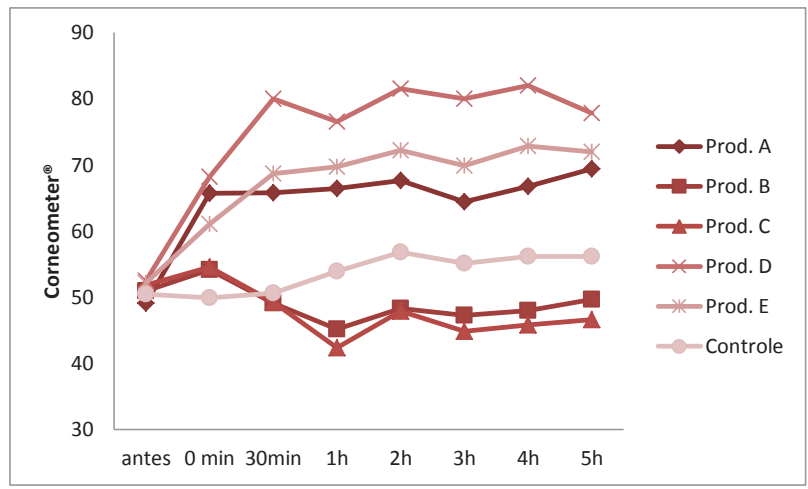

Figure 3 / Figura 3. Hydration capacity of each product, according to the time intervals analyzed Perfil de hidratação de cada produto, conforme o tempo
O perfil de hidratação de cada produto, ao longo do tempo, pode ser observado na Figura 3. Conforme esperado para cremes hidratantes, os produtos "A", "D" e "E" aumentaram significativamente a hidratação cutânea, por até $5 \mathrm{~h}$, em relação à área controle. Já os produtos " $\mathrm{B}$ " e " $C$ " não demonstraram capacidade de melhorar a hidratação cutânea, em relação à área de controlo.

A perda de água transepidérmica foi medida, expressa em $\mathrm{g} /$ $\left(\mathrm{m}^{2} \mathrm{~h}\right)$, nos mesmos intervalos de tempo, com o Tewameter ${ }^{\circledR}$. Foi calculada a média geral correspondente à área de aplicação de cada produto, conforme Figura 4.

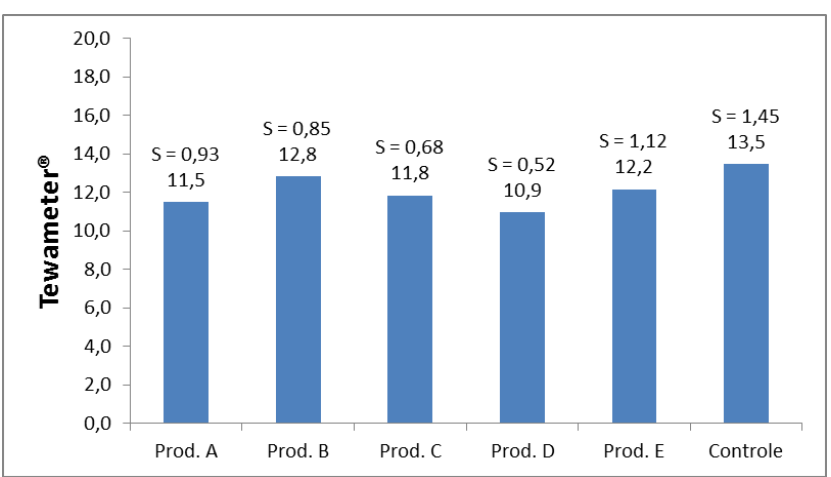

Figure 4 / Figura 4. Transepidermal water loss averages in the areas treated with moisturizers and in the control area over the total time of the study, displaying a $95 \%$ level of confidence

Perda média de água transepidérmica, ao longo de todo o estudo, nas áreas tratadas com os produtos e na área controle, exibindo um nível de confiança de $95 \%$ 
Paired t-tests were also applied to the data in order to compare ese were grouped according to the difference of water loss. As can be seen in Table 3, during the studied time interval, the product " $\mathrm{D}$ " prevented transepidermal water loss better, confirming the results of improvement from skin hydration.

Transepidermal water loss after application of each product, according to time, can be seen in Figure 5. The study indicated that product " $D$ " was the most effective in preventing transepidermal water loss for up to five hours after application, reducing it significantly compared to the control area.
A estes dados também foram aplicados testes t pareados, visando à comparação entre os produtos. Esses foram agrupados quanto à existência ou não de diferença significativa de perda de água. Conforme se pode observar na Tabela $\mathbf{3}$, durante todo o intervalo de tempo estudado, o produto " $\mathrm{D}$ " foi o que melhor preveniu a perda de água transepidérmica, corroborando o resultado de melhor performance hidratante apresentado na Tabela 2. Os demais produtos também foram capazes de prevenir a perda de água nas áreas tratadas, em comparação com a área de controlo.

A perda de água transepidérmica após a aplicação de cada produto, conforme o tempo, pode ser observada na Figura 5. Nota-se que o produto "D" foi o mais eficaz na prevenção da perda de água transepidérmica, reduzindo-a significativamente, em relação à área controle, por até 5 h após a aplicação.

Table 3 / Tabela 3. Products divided into groups, with significant differences in prevention of transepidermal water loss

Divisão dos produtos em grupos, com diferença significativa na prevenção da perda de água transepidérmica

\begin{tabular}{|c|c|c|c|c|}
\hline Produto & Tewameter & 1 & 2 & 3 \\
\hline Product / Produto D & 10,9 & $* * * *$ & & \\
\hline Product / Produto A & 11,5 & & $* * * *$ & \\
\hline Product / Produto C & 11,8 & & $* * * *$ & \\
\hline Product / Produto E & 12,2 & & $* * * *$ & \\
\hline Product / Produto B & 12,8 & & $* * * *$ & \\
\hline Control / Controle & 13,5 & & & $* * * *$ \\
\hline
\end{tabular}

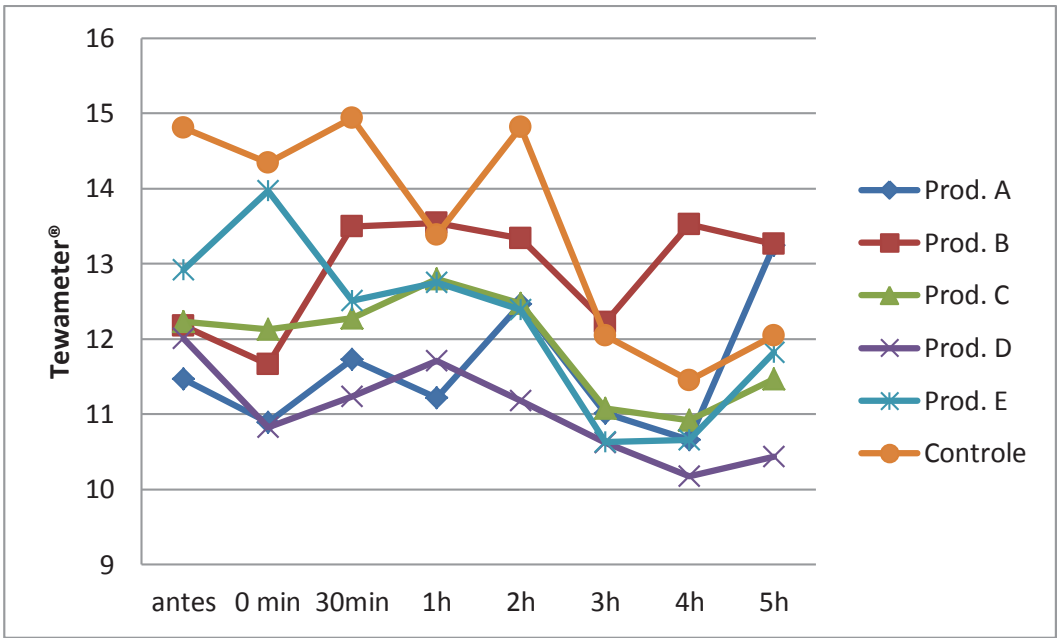

Figure 5 / Figura 5. Transepidermal water loss after application of each product, according to the time intervals analyzed

Perda de água transepidérmica após a aplicação de cada produto, conforme o tempo 


\section{Discussion}

It is known that urea-containing formulations influence the properties of the skin barrier, reducing transepidermal water loss and increasing hydration. Although the exact mechanism of urea's action is unknown, the improvement in barrier function may be related to an increase of corneocyte size $[8,9]$.

There are several moisturizers on the market whose main claim is the presence of urea at $10.0 \%$. This study indicated that, despite having the same active substance in the same concentration, they demonstrated different abilities of skin hydration and prevention of transepidermal water loss.

In this study, product " $D$ " showed the best ability of skin hydration and the best prevention of transepidermal water loss and it was consistent to assume that these two parameters were directly related.

Comparatively, the areas treated with the remaining products (A, B, C and E) showed less hydration and significantly higher transepidermal water loss.

However, compared to the control area, these products were also able to improve skin's barrier, reducing the transepidermal water loss and increasing skin hydration, suggesting that the $10 \%$ concentration of urea in cosmetics is effective moisturizing $[12,13]$.

Different substances can contribute to skin hydration by occlusion or wetting, but the intensity of each action is distinct. Moreover, the synergism and quantity of the components in each product are important parameters to analyze.

To better evaluate the moisturizing capacity of each product, it would be necessary to know the amounts of each component in formulations, and also important to consider possible interactions between them.

\section{Conclusion}

The skin hydration average of all treated areas increased significantly compared to untreated area, during the five hours analyzed. However, moisturizer "D" showed better skin hydration capacity with lower transepidermal water loss, in spite of containing urea at the same concentration of the other creams.

The variations in these results show the importance of testing equivalence for topical products because, as demonstrated in this study, although certain products contain the same active substance, differences in their

\section{Discussão}

Sabe-se que formulações contendo ureia influenciam as propriedades da barreira cutânea, reduzindo a perda de água transepidérmica e aumentando a hidratação. Embora o mecanismo exato da ação da ureia seja desconhecido, a melhora na função da barreira pode ser relacionada com um aumento do tamanho do corneócito $[8,9]$. No mercado, existem diversos produtos hidratantes cujo claim principal é a presença de ureia em concentração de $10 \%$. Este estudo indicou que, apesar de possuírem a mesma substância ativa, em igual concentração, eles divergem quanto à capacidade de hidratação cutânea e quanto à prevenção da perda de água transepidérmica.

No presente estudo, o produto D foi o que apresentou melhor capacidade de hidratação cutânea e melhor capacidade de prevenção da perda de água transepidérmica, sendo coerente inferir que estes dois parâmetros estejam diretamente relacionados.

Comparativamente, as áreas tratadas com os demais produtos (A, B, C e E) apresentaram hidratação inferior e perda de água transepidérmica significativamente maior.

Porém, em relação à área controle, todos os produtos demonstraram ser capazes de melhorar a barreira superficial da pele, diminuindo a TEWL e aumentando a hidratação cutânea, sugerindo que a concentração de $10 \%$ de ureia, em cosméticos hidratantes, seja efetiva $[12,13]$.

Diferentes substâncias podem contribuir com a hidratação cutânea, seja por oclusão ou umectação, porém a intensidade da ação de cada uma delas é particular. Além disso, deve-se considerar o sinergismo e a quantidade dos componentes presentes em cada produto.

Sendo assim, para que se possa discutir a diferença de desempenho hidratante de cada produto, é necessário conhecer as quantidades dos componentes presentes em cada formulação, bem como estudar as possíveis interações entre elas.

\section{Conclusão}

A hidratação cutânea média de todas as áreas tratadas aumentou significativamente em relação à área não tratada durante as 5 horas analisadas. Porém, dentro desse intervalo, o creme hidratante " $D$ " apresentou melhor capacidade de hidratação cutânea com a menor perda de água transepidérmica, mesmo contendo uréia na mesma concentração dos demais cremes.

As variações nos resultados obtidos apontam a importância da realização de testes de equivalência também para produtos de aplicação tópica, pois, conforme 
vehicles' composition can alter the ultimate effectiveness.

\section{Conflict of interests}

The authors declare that there are no financial or personal affiliation that could be viewed as a potential conflict of interests. demonstrado, por mais que determinados produtos contenham a mesma substância ativa, diferenças na composição de seus veículos podem alterar a eficácia final do produto.

\section{Conflito de interesses}

Os autores declaram que não existem relações financeiras ou pessoais que puderam ser vistas como um potencial conflito de interesses. 


\section{References / Referências}

[1] Euromonitor. Disponível em: <http://www. euromonitor.com/colour-cosmetics-in-brazil/report>. Acessado em: 23/04/2013.

[2] Draelos ZD. Cosmecêuticos. Elsevier: Rio de Janeiro 2005. 264 p. Heald P, Burton CS, Callaway L. Moisturizing the Skin. N C Med 1983;44(4):234

[3] Addor F. Skin barrier in atopic dermatitis Anais Bras Dermatol. 2010; 85(2):184-94.

[4] Albèr C. Effects of water ingredients and use of urea on skin ultrastructure evaluated by confocal Raman microspectroscopy. Bioch Biophys Acta. 2013; 1828(2):2470-8.

[5] Yokota M, Maibach HI. Moisturizer effect on irritant dermatitis: an overview. Contact Dermatitis. 2006;55:65-72.

[6] Leite-Silva V. Hydrating effects of moisturizer activecompounds incorporated into hydrogels: in vivo assessment and comparison between device. J Cosmetic Dermatol. 2009;8(1):32-9.
[7] Jacobi OK. Moisture regulation in the skin. Drug Cosmet Ind. 1959;84:732-812.

[8] Watabe A. Sweat constitutes several natural moisturizing factors, lactate, urea, sodium, and potassium. J Dermatol Sci. 2013;72(2):177-82

[9] Rosado C. Assessment of impact of a cream containing urea in skin barrier function. Revista Lusófona de Ciências e Tecnologias da Saúde, v.41, n.2, p. 166-173, 2008.

[10] Lodén M. Barrier recovery and influence of irritant stimuli in skin treated with a moisturizing cream. Contact Dermatitis. 1997;36:256-60. Buraczewska I.; Brostrom UB.; Lodén M. Artificial reduction in transepidermal water loss improves skin barrier function. British J. Dermatol. 2007;157(1):82-6.
[11] Tecnotests. Disponível em: <http:/ www.cosmeticsonline.com.br/produtos/ arquivos/A27_manual_mpa5_port_corneometer 18-03-09.pdf>. Acessado em: 23/04/2013

[12] Addor F. The skin moisturizing effects of different concentrations of urea: a clinical and corneometry study. Surgical \& Cosmetic Dermatology 2009;1(1):5-9.

[14] Polaskova J. Moisturizing effect of topical cosmetic products applied to skin. J Cosmetic Sci. 2013;64(5):329-40. 